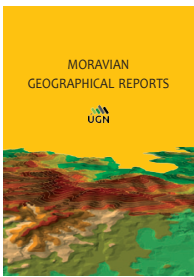

MORAVIAN GEOGRAPHICAL REPORTS

The Czech Academy of Sciences, Institute of Geonics

journal homepage: http://www.geonika.cz/mgr.html

doi: https://doi.org/10.2478/mgr-2020-0007

\title{
How and why did craft breweries 'revolutionise' the beer market? The case of Poland
}

\author{
Bartosz WOJTYRA ${ }^{\text {* }}$
}

\begin{abstract}
Since 2011, when the Pinta Brewery brewed the first AIPA-style beer in Poland, dynamic growth of the craft beer market has been observed. While there were 70 breweries in 2010, in 2019 there were already about 420, most of them small. The number of new beers on the market also increased rapidly each year in the analysed period, from around 80 in 2013 to about 2,500 in 2019. Similar changes were noted in other countries, including the USA, where it was accepted to call this phenomenon 'the craft beer revolution'. The aim of this paper is to indicate the reasons for the emergence and development of this process, using Poland as a case study. Based on statistical data and content analyses, as well as studying the modern history of the beer market, the distribution of craft beer pubs and the names of craft breweries, this work provides evidence that the proliferation of microbreweries in Poland can be confirmed by concepts such as a resource-partitioning model, neolocalism, path dependence, and the diffusion of innovations.
\end{abstract}

Key words: craft beer revolution, craft beer market, neolocalism, path dependence, resource-partitioning model, Poland

Article history: Received 31 December 2019, Accepted 20 May 2020, Published 30 June 2020

\section{Introduction}

After 1989, Poland gradually became an important player among beer producers in Europe and was among the leading countries in which this drink is the most consumed per capita (The Brewers of Europe, 2017). This was primarily the effect of the entry of large international brewing concerns into Poland in the 1990 s, taking over declining smaller breweries. As a result, the beer market transformed into an oligopoly in which only three large producers played a significant role (e.g. Boratyńska, 2009; Borowska, 2009; Gołaś and Ścibek, 2010). An additional outcome was the progressive homogenisation of beer. Basically, brewing companies offered only one style of beer for distribution, classified as International Pale Lager, which shaped the tastes and palates of Polish people for many years.

An answer to the expectations of consumers seeking new flavours came in 2011, when the Pinta Brewery first brewed a beer in the style of AIPA (American India Pale Ale) in Poland. From this moment on, a dynamic growth of the craft beer segment can be observed (Wojtyra and Grudzień, 2017, Wojtyra et al. 2020). While in 2010 there were 70 breweries in the country, in 2019 there were about 420 . The vast majority of these companies were small craft breweries offering strongly diversified products, referring to the richness of beer culture. In the analysed period, the amount of new, unique beers presented annually by Polish breweries was also growing rapidly - from 82 in 2013 to about 2,500 in 2019. Similar changes were recorded earlier in other countries, including primarily the USA, where it was accepted to describe this phenomenon as the 'craft beer revolution' (e.g. Acitelli, 2013; Patterson and Hoalst-Pullen, 2014; Pokrivčák et al., 2019; Swinnen and Garavaglia, 2018). The development of craft brewing markets, however, was uneven in time and space (Patterson and Hoalst-Pullen, 2014). The 'Polish beer revolution' has some analogies to the American one, but its character is the result of local specificities and the later start.

The main aim of this research project is to examine the reasons for the dynamic changes in the craft beer market in Poland that took place after 2011, during the so-called craft beer revolution. The basic questions are: What led to the dramatic change in the craft beer market in Poland? Further, why did the craft beer revolution spread so quickly and systematically. Finally, the project tries to explain, from a theoretical point of view, what were the factors leading to the Polish craft beer revolution. On the one hand, using Poland as a case study, the phenomenon could be explained on the basis of well-established theories in the field of economics

\footnotetext{
${ }^{a}$ Department of Agriculture and Rural Geography, Faculty of Human Geography and Planning, Adam Mickiewicz University in Poznań, Poland (*corresponding author: B. Wojtyra, e-mail: bwojtyra@amu.edu.pl)
} 
or socio-economic geography and scientific literature about the beer market, drawing mainly on the experience of other countries. On the other hand, an empirical exploration of this phenomenon was designed in terms of statistical data analysis, content analysis and descriptive methods. The time period for the project related to the course of the craft beer revolution, the years 2011-2019. To include an historical context, some information and analyses referring to earlier periods are presented, as a background and context for the diagnosed changes.

Since the phenomenon of craft beers has been observed in Poland for only a few years, this subject has not been examined before - up to the present research on the Polish beer market has referred primarily to the production of the largest beer companies (e.g. Boratyńska, 2009; Borowska, 2009; Gołaś and Ścibek, 2010; Huculak, 2004; Klimek, 2014; Kopeć and Mitera, 2014; Łoboś and Szewczyk, 2013). Nonetheless, there are a few publications partly devoted to the craft beer market and the craft beer revolution in Poland. Such works usually relate to quantitative research in the field of management and the spatial distribution of breweries (Chlebicka et al. 2018; Łużak, 2017; Maszkowski and Wysokiński, 2017; Niemczyk, 2017; Podeszwa, 2015; Wojtyra and Grudzien, 2017, Wojtyra et al., 2020). In comparison, this article is an introduction to detailed studies on the craft beer market in Poland. In this attempt to explain the phenomenon, the basic references are to empirical publications in the field of the geography of industry, human geography, cultural geography and economics.

This paper is divided into five sections. In the next one, a theoretical background for the proliferation of the craft beer movement in the world is presented. In the third part, attention is paid to data and methods. The fourth section is focused on the characteristics of the craft beer market in Poland. The fifth part concerns the results and findings, especially some of the main reasons for the proliferation and development of the Polish craft beer market. Relevant conclusions are drawn at the end of the article.

\section{Theoretical background: The proliferation of the craft beer movement in the world}

\subsection{Origins of the 'craft beer revolution'}

The term 'craft beer revolution' originated in the USA, where it was used for the first time to describe the changes in America's craft beer market that took place in 1965 when Fritz Maytag rejuvenated the Anchor Steam Brewery. The phenomenon was also the result of home brewing legalisation by Jimmy Carter in 1979. In the United Kingdom, on the other hand, "The Campaign for Real Ale" (CAMRA) was founded. This independent voluntary consumer organisation was opposed to the growing mass production of beer and the homogenisation of the British brewing industry (see, for example: Acitelli, 2013; Elzinga et al., 2015; Hindy, 2014).

The 'craft beer revolution' is a term proposed in the literature to describe the phenomenon of a dynamic increase in the number of craft breweries and their new products, as well as the popularity of craft beer. It is a concept defining the fashion for consuming such products. The slogan 'revolution' does not concern the scale of production, but a qualitative increase in general terms. On the one hand, the qualitative change primarily concerns the extension of brewers' offers to new beers, especially from the ale family, which are in opposition to the popular International Pale Lager. Craft breweries brew beer in almost all available 100 styles of beer (BJCP, 2015); in addition, they often introduce variations on these classic styles and also recreate historical types of beer. Therefore, the craft beer revolution is a retreat from the one style of beer as mass-produced by large concerns. On the other hand, a quantitative change is manifested in the rapid growth of new brewing entities in the groups of microbreweries, restaurant breweries, brewpubs, and contract breweries. Earlier, this form of brewing activity was not widespread. In addition, a dynamic growth of new unique brands of beers on the market is noticeable, often brewed in short series, available only temporarily, seasonally, depending on global trends, but not regularly returning to the market. In fact, the phenomenon of the craft beer revolution is evolutionary and should not be equated with the literal meaning of the term 'revolution'. This slogan was captured in the science literature from industry nomenclature and the mass media. It seems that it is currently recognisable and clearly defines the researched phenomenon. The number of publications where it is used is indicative of that (Rice, 2016).

The origin of this term can be associated with the need to emphasise the distinctness of the activities of craft breweries in relation to what was proposed by large industrial breweries. This terminology was significant from a marketing point of view and is like a stylistic hyperbola. Especially at the beginning of the craft beer revolution, the people involved in it described themselves as rebels who are looking for the possibility to choose the beer because of taste, quality, or style (Moore et al., 2016; Rao, 2008; Rice, 2016). For example, the Scottish brewery Brew Dog often invokes revolutionary slogans in their marketing campaign ("The Resistance", "Equity for Punks": Cabras and Bamforth, 2015). Currently, they are emulated by many other craft breweries, including the Polish Pinta Brewery, on whose labels we can find the slogan "Original Craft Beer Revolutionaries". Many Polish brewers emphasise their independence and willingness to create niche, experimental, interesting, unusual and high-quality products - as one example, the Golem Brewery defines its marketing strategy as "uncompromising contract brewery", and its mission statement is "Go big or go home!"

The "craft beer revolution" is an international phenomenon. Poland, due in part to the development of the craft beer industry, similar to that in many other countries of the world, has become part of this revolution. In addition to the cradle of this phenomenon, i.e. in the United States, the dynamic growth in the number of breweries in recent decades has been noted in many other countries of the world, including Italy, the Netherlands, the United Kingdom, Canada, China, Japan, Australia, Denmark and Brazil. It is also visible in countries with a deeply-rooted and developed market for traditional small breweries, such as the Czech Republic, Germany, and Belgium (e.g. Cabras et al., 2016; Elzinga et al., 2015; Esposti et al., 2017; Fastigi et al., 2018; Patterson and Hoalst-Pullen, 2014; Pokrivčák et al., 2019; Swinnen and Garavaglia, 2018 - see Figs. 1A and 1B).

\subsection{Resource-partitioning theory}

Beer is one of the most popular beverages in the world (e.g. Arnold, 2005; Oliver, 2012; Piron and Poelmans, 2016).

\footnotetext{
${ }^{1}$ See http://browargolem.pl/
} 
It has been known for ages and it is not "on the way out". Over the years, beer brewing techniques and beer styles have changed, also new ingredients have been introduced, e.g. hops (Hornsey, 2003). The process of refining beer experienced its peak in the $19^{\text {th }}$ and $20^{\text {th }}$ centuries as a result of industrialisation. Gradually, large international brewing companies producing beer on a global scale began to dominate the market. The use of more and more advanced methods should lead to an increase in production, a decrease in the cost of producing a beer bottle, and maximising profits. Such strong competition and high entry barriers affected the consolidation of the global brewing industry and the formation of oligopolies in beer markets in many countries (e.g. Swinnen and Garavaglia, 2018). According to M. Porter (1980, p. 9): "in the brewing industry, product differentiation is coupled with economies of scale in production, marketing and distribution to create high barriers." Thus, the changes that took place at the turn of the $21^{\text {st }}$ century in many countries, including Poland, seem more surprising. A dynamic growth in the craft brewery sector appeared somewhat contrary to the logic and classical principles of economics, because small manufacturers exerted pressure on large breweries in terms of diversity in the product portfolio. An analogous situation in other oligopolistic markets seems hard to imagine (Niemczyk, 2017).

Primarily, the craft beer revolution can be based on the resource-partitioning model, an established model of organisational ecology (Carroll, 1985; Carroll and Hannan, 1995; Carroll et al., 2002). G. Carroll and A. Swaminathan (2000, p. 717) believe that the

"resource-partitioning theory explains the rise of late-stage specialist segments within an industry as an (unexpected) outcome of the consolidation occurring among large generalist organisations as they compete for the largest consumer resource bases of the mass market".

G. Carroll (1985) suggested first, that this model may also apply to the microbreweries market. According to resource-partitioning theory, as an industry takes on an oligopolistic structure, it often produces an increasingly

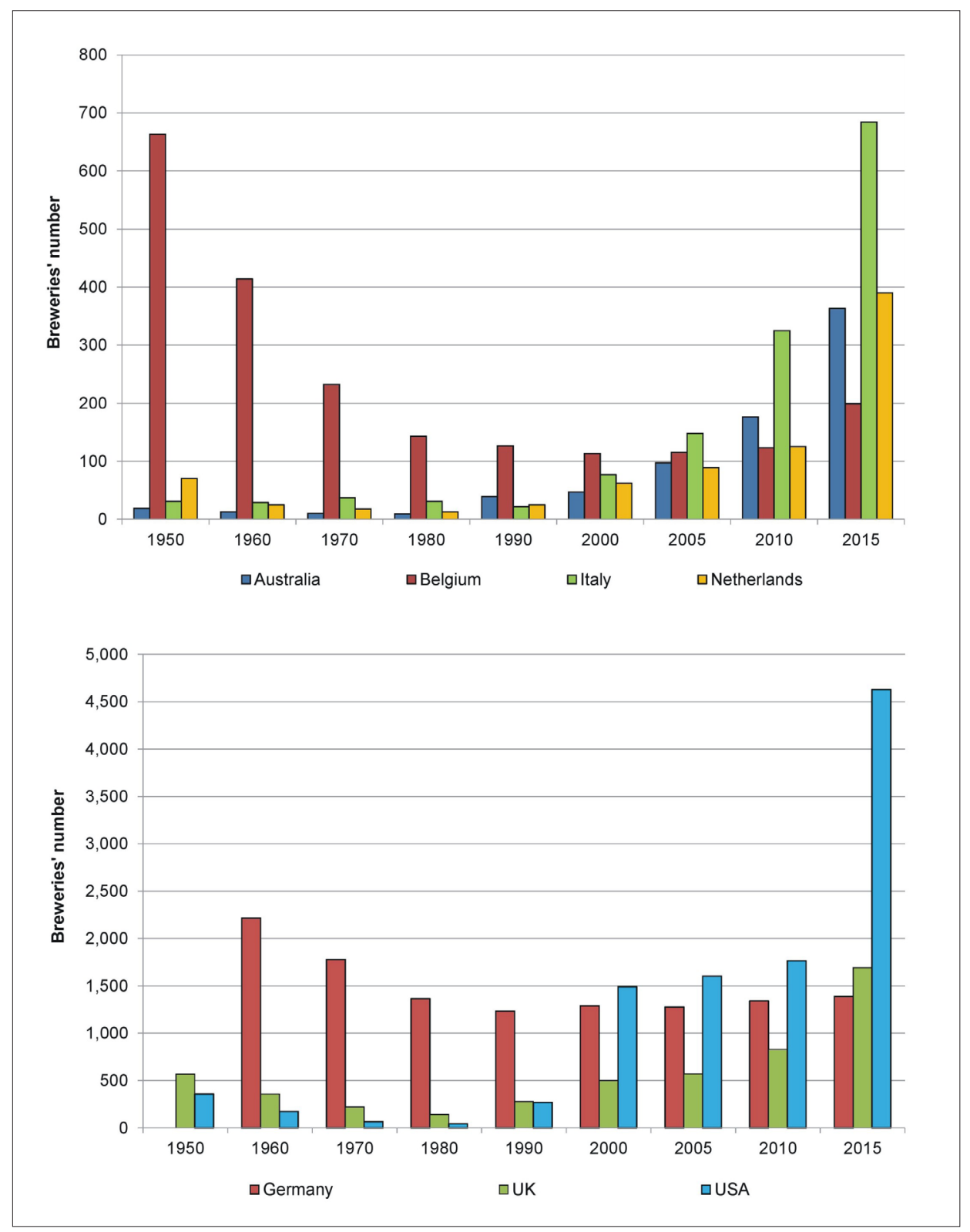

Figs. 1A, B: Changes in the number of breweries in selected countries in the years 1950-2015

(Note: different ordinate scales for these Figures)

Source: author's elaboration based on Swinnen and Garavaglia (2018) 
homogeneous product which depends on economies of scale in production, marketing, and distribution to consolidate its success. This situation favours the creation of a market niche, which can be used by small producers (Freeman and Hannan, 1983; Murray and O'Neill, 2012; Cabras and Higgins, 2016; Swaminathan, 1998). On the beer market, the progressive homogenisation of beer and the popularisation of International Pale Lager on a massive scale, caused by decades of consolidation, provided a chance to open a niche market for microbreweries. R. Caves and M. E. Porter (1977) claim that this niche market existed in what had been referred to as the "competitive fringe". In such a market niche, competition is based not only on the price level, but on competencies such as quality, innovation, and the ability to adapt to customer needs (Zuchella and Palamara, 2007). In contrast, large beer producers considered affordability to be the most important factor, particularly in low- and medium-income countries where more rapid economic growth encourages consumption (Blecher et al., 2018).

Considering the number of new, unique craft beers available on the market every year, what is very interesting is the so-called hyper-differentiation phenomenon. It is defined as an increasing importance of being truly different (Clemons et al., 2003). Hyper-differentiation leads to reducing the importance of prices as the principal factor behind customers' choice among alternative goods and services. Craft beer is a highly diversified product (Clemons et al., 2006). The team of E. G. Clemons (2006, p. 166) claim that "it may be particularly important to design a product that at least some consumers love, rather than developing a middle-of-the-road product." This situation stands in contrast to the strategy of the larger companies whose products should provide tastes for as many consumers as possible.

According to researchers from Slovakia (Pokrivčák et al., 2019, p. 66) "motivations to drink craft beer are generated by three important factors: desire for more knowledge, new taste experience, and move away from the mainstream beer consumption." Today, the role of consumers in the economy is changing. They are connected, better informed, and active rather than isolated and passive like several years ago (Prahalad and Ramaswamy, 2004). Consumers declare increasingly often their interest in regional products, manufactured using traditional methods, which can be associated with emphasising ethno-centric attitudes. They are curious about new flavours (Mastanjevic et al., 2019). Ecological awareness among consumers is also growing and they make purchasing decisions taking into account the environmental impact of the product. Studies have shown that consumers are willing to pay more for such products, including craft beers (Moon et al., 2002).

Consumption is often indicative of social distinction (Bourdieu, 1984). Drinks and food chosen by consumers are a form of identity expression (Blaiech et al., 2013; Dybka, 2015). The purchase of specific products personifies desires, values and aspirations. Also, drinking craft beer is an attempt to show an affinity with a group united around these types of products. Furthermore, beer can emphasise social status and prestige (craft beer drinkers as 'beer snobs': Toro-González et al., 2014). Baginski and Bell (2011) describe craft beer as a "high order prestige good".

It is also significant that the Millennial generation plays an important role in craft beer popularity in the vast majority of countries (Holtkamp et al., 2016; Moore et al., 2016). They value products that reflect their generation. Millennials are among the most committed purchasers of sustainable products and services, and they are willing to pay higher prices for environment-friendly goods (Holtkamp et al., 2016). The role of the Internet, especially social media, is also significant: it is the main medium that craft breweries use to communicate with this generation of customers (Reid et al., 2014).

\subsection{Globalisation and diffusion of innovations}

It seems that globalisation does have an impact on the development of the craft beer market. On the one hand, it promotes the homogenisation of food products and the creation of the same needs and preferences among consumers worldwide, which resulted in the success of International Pale Lager. The needs and palates of customers, as well as the culture of drinking beer, were unified and satisfied by standardised products supplied by brewing concerns (Stack et al., 2016). The beer market has been subject to a phenomenon sometimes described as 'McDonaldization' (Ritzer, 1993). This, in turn, caused the birth of the so-called 'anti-mass production movement' (Rao, 2008), expressing an opposition to progressive homogenisation by creating and promoting products such as craft beer, which are diverse, atypical, and high-quality. Glocalisation as counter-globalisation was also a response to the globalisation process, i.e. promotion of local traditions or specific local resources that could be offered on the global market (Robertson, 1994). One of the results of counter-globalisation is that in the last two decades the term local has taken on a new meaning (Schnell, 2013: further developed here in subsection 2.4). This has also led to support for the idea of craft breweries.

On the other hand, thanks to the development of globalisation, the world is becoming a place of fast knowledge and information transfer. Globalisation has led to the compression of time and space (Harvey, 1989). First of all, in the social sciences an increase in relationships between people is emphasised. Contact between people all over the world is direct, e.g. by traveling, and indirect, e.g. because of the development of the Internet. Globalisation has allowed the intensification of social relations that connect those living in distant places (Giddens, 1990). As a result, the flow of ideas is faster. Information sharing is more frequent and more effective. Thus, globalisation has made it possible to transfer the idea of craft beer between continents.

Transfer of information after introducing a new product on the market starts the process of the diffusion of innovations, in which the producers, buyers, and future followers take part. M. Brzeziński (2001) writes that diffusion of innovation is a process of spreading and popularising innovation in the company and the economy; occurring when it is adopted by other enterprises after the first successful application of a new technical or organisational solution. From the clients' point of view, the process of diffusion of innovation relates to the acceptance and dissemination of a given product by society (Rogers, 1962). An unquestionable advantage of craft breweries is the tendency to transfer ideas, search for innovation, introduce changes and learn. By experimenting with recipes, microbreweries are trying to achieve popularity, build a brand and at least for a moment attain a privileged position on the market.

In a fledgling market, cooperation and knowledge transfer between breweries play a significant role, especially in the case of contract breweries whose business models are based on cooperation with stationary breweries (Tomski and Menderak, 2019). Despite market competition and 
acting in a market niche, unification around a common idea allows for a strengthening of the industry (Mathias et al., 2018). According to the American Brewers Association, collaboration is a hallmark of the modern craft brewing scene and is one of the strategies that allow craft breweries to compete successfully against large brewing concerns (Nilsson et al., 2018). T. Acitelli (2013) claims that collaboration was particularly valuable for the early commercial craft brewers. In addition, the cooperation of breweries helps to improve the product quality, and to gain basic strategic knowledge about the industry and its regulations (Duarte Alonso et al., 2018).

\subsection{Neolocalism}

Another concept that can be associated with the development of the craft beer industry and related to globalisation is so-called neolocalism. It is an answer to the progressive unification of economies and lifestyle: Schnell and Reeese (2003) label it as the "smothering homogeneity of popular, national culture". Neolocalism, then, is a return to local traditions. It consists in rebuilding and nurturing them, and it can be defined as the conscious effort of enterprises to promote a relationship with a given place. This trend is an attempt to create a "new sense of place" (Flack, 1997; Holtkamp et al., 2016). There is extensive research determining what neolocalism is and how companies, including small breweries, identify with it and engage in it (e.g. Bell, 2017; Flack, 1997; Eberts, 2014; Garavaglia, 2020; Gatrell et al., 2018; Holkamp et al., 2016; O'Brien, 2020; Reid et al., 2014; Schnell and Reese, 2003, 2014; Yeager and Gatrel, 2020).

On the one hand, neolocalism can be said to support the emergence of the craft beer market. This is due to the growing number of people who want to re-establish connections with local communities, settings, and economies (Schnell and Reese, 2003). The lack of trust and skepticism towards large corporations is common among the Millennials, and is demonstrable in the expenses of consumers who prefer to spend money on local business and products rather than on domestic brands (Holtkamp et al., 2016). In turn, the niche was filled with craft breweries that emphasise their locality, smallscale production, and traditional brewing methods. W. Flack (1997, p. 49) argued that "microbreweries engender a strong, self-conscious attachment to their localities", indicating that microbreweries were an expression of a new desire for roots, as well as a conscious rejection of globalised society.

The search for a sense and connection with 'place' is behind the strong attachment to what is local, familial. This strategy is intended to encourage people to buy beer brewed this way (Hotlkamp et al., 2016). Consumers want to feel that a major part of their community by drinking beer that is clearly local or simply craft beer, which is basically brewed in a small, local brewery. They are not drinking a brand but an idea, which is often the connection to a place (Khermouch, 1995). As a result, informal groups of craft beer lovers are created. According to Nielsen's report (2015) regarding consumer trends in the craft beer industry in the US, about half of all craft beer drinkers consider whether the beer is local when making purchasing decisions. In turn, according to the 2018 Totta Research report, craft beer lovers value locally-brewed beer, but interestingly, where the beer comes from is less important, and how the beer is produced is more important. The key for consumers is beer made from fresh, local ingredients, and available in a wide range of different types of products (DSM, 2018).
Neolocalism is manifested in the craft beer industry primarily in the simplest and most common way, i.e. through a marketing strategy that uses names, symbols referring to locality, geography, the history of the place, and its features (e.g. Bell, 2017; Eberts, 2014; Schnell and Reese, 2003). A local reference may include: the name of the brewery; the name of the beer; or a label that uses a symbol; a graphic or a photograph referring to the locality. Craft breweries present their connection with locality using dialect expressions in the name of the beer, or local ingredients in the production of the beer (Garavaglia, 2020). Besides, it may occur in the slogans and other commercial activities: e.g. in information on the official websites (Materna et al., 2019). In this way, breweries try to build customer loyalty through their attachment to place, but it is a difficult task as indicated in the Totta Research report, where it was found that craft beer drinkers like to experiment and to look for other flavours among craft beers. Therefore, they might be more often attached to the craft beer movement, per se, and to the locality represented by craft breweries as a part of the industry - rather than to the specific "places" that the breweries represent.

\subsection{Path dependence theory}

It seems that one of the justifications for the development of the craft beer industry is the theory of path dependence. P. David (1985) and B. Arthur (1989) published papers that are considered the basis for the literature on path dependence. They claim that sub-optimal or inefficient technologies may be locked in as industry standards. The concept of path dependence makes it possible to explain cases that contradict the predictions of previous theories, or those cases that were impossible to explain from that perspective.

When a product is recognised as an industry standard, and when consumers or users invest time or money in learning a particular system or in the convenience of using traditional practice, they will be less likely to try a competitive process, even if it produces better results over time.

This so-called behavioural lock-in occurs when a process, product or service "gets stuck" on a non-optimal path, when a habit or organisational culture prevents change. Because a particular food or drink is rooted in culture, it can be very difficult to change the common perception of what this product is and what it can or should be. This is also the case for beer, and more specifically for International Pale Lager (Choi and Stack, 2005; Stack et al., 2016). Only one style became synonymous with beer, although the richness of the beer world is much greater.

For large brewing corporations, changes in the production direction are very costly and would have to be supported by market needs. As a result, breaking such dominance and trapping in the path can only occur through a deep and rapid change in the system environment, known as "the turning point" (Martin, 2010). The growth of the craft beer market is based on the fact that large corporations are locked in the direction of production. The turning point in the beer market came in each country unofficially at a different moment. For example, in the Netherlands the proliferation of microbreweries was caused by the launch of the first new brewery since World War II (De Arcense Stoombierbrouwerij). In Australia, craft brewing began around 1980 and is linked with the creation of the Sail and Anchor brewery. In Spain, it started in 1989 when Jaime Tejada opened Naturbier (Swinnen and Garavaglia, 2018). 


\section{Data and methods}

This project uses both primary and secondary data. As materials for the identification, characteristics, and evaluation of the change in the number of breweries and craft beer pubs, "The Beer Map", created by a group of Polish "beergeeks", known for their involvement in the craft beer scene in Poland and available on Google maps, was used. This information was verified by Internet sources (e.g. Untappd, Ratebeer, Piwna Zwrotnica, official websites, and the social media channels of breweries), press materials, and interviews with people associated with Polish breweries. The study used statistical data about GDP from World Bank resources. The Brewers of Europe and Statistics Poland reports were the bases for the analysis of production and the consumption of beer. The Birofilia report about the Millennial generation was also analysed in the context of Polish beer consumers.

The basic method used in this article is the case study report, for which the craft beer market in Poland was selected. The outcome is a detailed and comprehensive report: analysis of this report reflects the phenomenon in a holistic way, and enables the reader to draw conclusions on the causes and effects of the functioning of this particular phenomenon (e.g. Gerring, 2007; Stake, 1995). It is mainly used in descriptive research issues, especially those that focus on answering "how" and "why" questions, and results from a desire to understand complex social and economic phenomena (Yin, 2009). A special advantage of this method is that it refers to actual practice, which makes it an effective tool (Flyvbjerg, 2006) and further states that it is possible to generalise on the basis of a single, well-documented case. Thus, the method might be the basis for further testing of hypotheses and support for theoretical knowledge. A discipline without a large number of exemplars is ineffective (Kuhn, 1987).

Examining the case study, descriptive methods and content analyses were also used. The characteristics of the craft beer market began with an overview of the historical determinants of the development of the brewing industry in Poland, focusing on its modern history. The experience of other countries clearly indicates that the development of this sector is strongly associated with socio-economic and political changes that take place in a given country.

In the following section, legal conditions were analysed and the course of the beer revolution was described, indicating dynamics, milestones, and effects of this phenomenon. Using this analysis, it is possible to compare the Polish case with the history of other countries in which the revolution happened. By analysing market development, it is possible to evaluate the importance of resource-partitioning theory and path dependence, in the context of the emergence of the craft beer movement as a market niche.

Section 5 focuses on the analysis of statistical data and the evidence collected. The relationship between income and consumption of beer was supported by a linear analysis. In the context of the development of craft beer culture, a proportional symbolic map of craft beer pubs for cities was drawn. Finally, by analysing the names of Polish craft breweries, the role of neolocalism in the craft beer revolution was evaluated.

\section{Profile of the case study: The craft beer market in Poland}

\subsection{Modern history of the Polish beer market (1918-2018)}

The modern history of the Polish beer market is very turbulent and strongly reflects the political and economic changes that took place over the period 1918-2018. The Polish brewing industry experienced years of crises and prosperity caused by two world wars, the transition to a centrally planned economy, and finally the construction of a free market economy during the political and economic transformation after 1989.

World War I covered 90\% of the Polish territory and caused huge damages, especially to industry and agriculture. The provision of goods was in very poor conditions and inflation was galloping. All of these factors also affected the beer market. While in 1914 there were about 500 breweries in Poland (at that time Poland had different borders than at present), in 1919 only 280 were opened. In subsequent years, however, their number dropped very quickly. In total, 112 breweries closed in 1920-1935 (Szymański, 2018). Of course, the operational scale of these breweries was incomparable to today's market leaders.

During World War II, many breweries disappeared. The economic reconstruction of the country after the conflict took decades, and, as a result, Poland came under the influence of the Soviet Union. Immediately after the Second World War, about 120 brewery plants were launched, but unfortunately few of them had facilities allowing production on a larger scale. During the period of the functioning of the centrally planned economy, about 100 breweries operated, but earlier all of them had been nationalised in stages. Then, the market was gradually decentralised. The stagnation of beer production occurred in the 1970s and 1980s and caused economic problems that transformed even in a political crisis in this period (Hána et al., 2020). State-owned farming kept Polish brewing away from the world, as well as from real competition forcing the improvement of production organisation and care for quality (Szymański, 2018).

After the collapse of socialism in 1989, the Polish brewing industry found itself part of strong global trends which resulted in the spectacular takeovers, the creation of large brewing groups, and changes in the production volume and supply. Since the economic transformation in the early 1990s, the beer sector in Poland has experienced the highest dynamics of beer consumption in Europe. This was the effect of the successful restructuring process of the Polish economy, changes in marketing practices, the increasing the quality of beer, income, and living standards. As a result, beer has become the most popular beverage in Poland (see Fig. 2).

Therefore, the beginning of the political and economic transformation in Poland was relatively good for large breweries, which quickly went through the process of privatisation and commercialisation. Local breweries were sold out mainly to foreign investors, i.e. international brewing groups such as Heineken, SAB Miller and Carlsberg. The changes resulting from these strong globalisation processes on the beer market in Poland led to having three major brewing companies, accounting for over $80 \%$ of the volume of beer sales in the country (Huculak, 2004). The process of consolidations and expansions of global beer corporations and privatisation in Poland was similar to the situation in other Central and Eastern European countries (e.g. Howard, 2014; Pokrivčák et al., 2019; Swinnen and van Herck, 2011). There are certain differences in the success of global beer corporations in this region, however, because of different traditions in consumer behaviour. In fact, acquisitions were especially successful in Poland, where, after the shutdown of small and regional breweries, original brands could still be promoted as regional beers (Materna et al., 2019). 


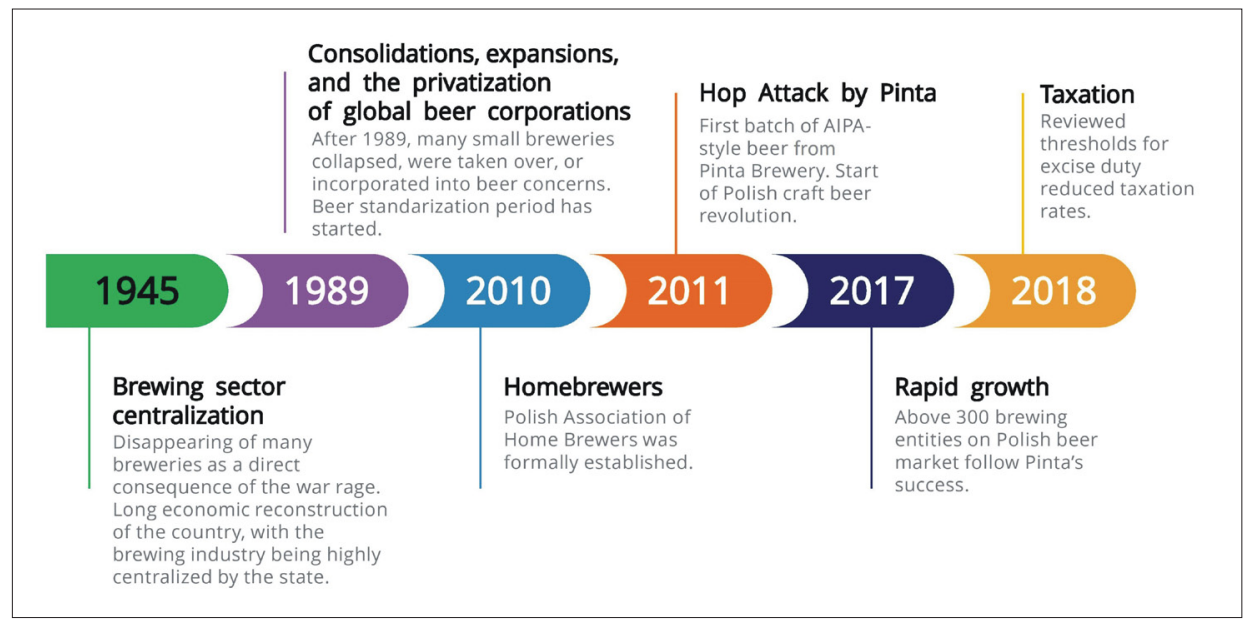

Fig. 2: Modern history of the Polish beer market

Source: Wojtyra et al. (2019)

The beginning of the transformation was difficult for smaller plants which were not able to struggle with an increasingly oligopolistic competition. In the years 1989 2010, many small- and medium-sized breweries were closed. In 1990 , only 79 breweries were active, and their number had not changed significantly for years (Huculak, 2010). But the first signs of bottom-up entrepreneurial initiatives in the sector appeared then. Medium-sized regional breweries (with an annual production at the level of 20,000 hl up to 200,000 hl), such as Regional Breweries Jakubiak or Amber Brewery, were established at that time.

The technology and scale of production, as well as the level of beer consumption, have changed over the years, especially as intensive development of the industry was observed in the $21^{\text {st }}$ century. Compared to 1995, in 2015 there was a five-fold increase in technical work efficiency from $1,100.00 \mathrm{hl}$ to $5,700.00 \mathrm{hl}$ per employee. Record investments in the brewing industry took place in 2000 , when they exceeded 0.9 billion $\mathrm{PLN}^{2}$. Since 2005, the net profit of the sector has been stable and is about 1 billion PLN per year (Szejner, 2017). In Eastern Europe, after 2008 and the global crisis, the beer market continued to grow only in Poland, while in other countries it remained stagnant or a downward trend was observed (Hána et al., 2020). In fact, the Polish beer market became one of the largest in Europe. According to 2017 production data, Poland ranks third in Europe, behind Germany and Great Britain. Considering the consumption of beer per capita, Poland takes fourth place, behind the Czech Republic, Austria, and Germany (Brewers of Europe, 2018).

\subsection{Craft brewery and craft beer: Terminology in Poland}

Both in Poland and in many other countries, the terms "artisanal brewery," "microbrewery," "independent brewery," or "local brewery", are sometimes used to describe breweries which brew different types of beer on a "small" scale, which distinguishes them from the mass-produced beer from large breweries. Interestingly, there is no official definition of a craft brewery in Poland. This is in contrast to many countries, e.g. the USA or Italy, where craft brewery is generally defined usually by size (production volume), the production process (traditional or innovative), and its ownership (status of being controlled by a concern; Swinnen and Garavaglia, 2018).
In 2018, the Polish government proposed to lower the beer excise duty rate for smaller breweries, and created the definition of a small brewery according to which this is an enterprise producing up to $200,000 \mathrm{hl}$ per year. In fact, this definition raises further doubts. This is especially the case with the development of small breweries associated with their gradual development and increase in sales, and which then could change their classification. In turn, other mediumsized breweries, focused on the production of a permanent offer of beers based on International Pale Lager, will belong to the group of craft breweries.

According to an unofficial definition of the Polish Association of Craft Breweries, this is an entity that produces or orders beer production which at the same time:

i. Puts the product quality first; in the beer production process, mainly traditional brewing, raw materials are used: water, malt, yeast, hops and the best and most current brewing knowledge;

ii. Is known for people making beer, a brewer or person responsible for production are known by name and surname, and are reachable for the end customer;

iii. Is innovative; through constant work on developing recipes and production technologies it contributes to the development of brewing knowledge; and

iv. Is independent; it is not personally or by capital connected with a larger producer of beer (a beer concern).

The proposed definitions are still vague, ambiguous, and inaccurate. It is really hard or even impossible to create a good qualitative definition, so the above-mentioned versions have caused a lot of controversy in Poland.

The tax thresholds, valid until 2018, have become the basis for an unofficial (but appearing in Polish literature) classification of breweries into three basic groups, which seem to be practical, although somewhat fixed (Wojtyra and Grudzień, 2017):

1. Small - annual production of up to $20,000 \mathrm{hl}$ (usually microbreweries, restaurant breweries, brewpubs);

2. Medium - annual production of $20,000-200,000 \mathrm{hl}$ (in Poland often named as regional breweries);

3. Large - annual production above $200,000 \mathrm{hl}$ (breweries controlled by concerns)

\footnotetext{
$21 \mathrm{EUR}=3.85 \mathrm{PLN}($ at $2000-12-29) ; 1 \mathrm{EUR}=3.86 \mathrm{PLN}(2005-12-30) ; 1 \mathrm{EUR}=4.26$ PLN $(2019-12-31)$
} 
A fourth group are contract breweries that are enterprises producing beer using production capacities hired from a stationary brewery with brewing installation ${ }^{3}$. The proliferation of the last group is one the main results of the craft beer revolution in Poland.

There is also no clarity as to the definition of craft beer. It can be stated that it is simply a craft brewery product, although there were some attempts to determine what craft beer is. In the Polish community associated with the craft beer market, it is most often defined as beer produced using a craft method by a small and independent brewery, where a brewer is known by name, and the production process and ingredients used are of a high quality ${ }^{4}$. The most popular definition of craft beer in Poland was created for the purpose of the "Kraft Roku" (The Craft Beer of the Year), the biggest commercial craft beer contest in Poland. Such a definition says that any submitted beer must be brewed commercially in an amount not exceeding $5,000 \mathrm{hl}$ per year, and by a brewer known by name.

\subsection{The emergence of a wave of craft breweries in Poland}

The Polish beer revolution unofficially began on the $28^{\text {th }}$ of March 2011, when the Pinta Brewery brewed in the Brewery at Jura, and then delivered on the market, the first batch of a beer called "Hop Attack", brewed in the style of an American India Pale Ale. This beer referred directly to the beer revolution in the USA. Unknown earlier to Polish consumers, non-typical raw materials, primarily hops imported from the USA and special malts in the Pintas beers, caused these products to be very popular. In turn, it resulted in a growing interest in craft beer among consumers (Wojtyra and Grudzien, 2017; Wojtyra et al., 2020).

In fact, the Pinta Brewery is the sixth contract brewery in the history of Poland, but only their establishment brought external effects and introduced the fashion for craft beer to Poland, as well as spreading this form of brewing activity, which is the contract brewery. The impulse for the establishment of this brewery was the success of A'la Grodziskie, the first beer brewed by one of Pintas owners, which was a reconstruction of the recipe of the defunct Polish beer style called Grodziskie. The beer had its premiere in June 2010 at the Birofilia Festival that had been the biggest beer event in Poland for many years.

Pinta's success had many followers. As a result, after 2011, new breweries began to appear in Poland, essentially microbreweries, restaurant breweries, brewpubs, and contract breweries, focusing on the production of the 'newwave' craft beers. They present a wide portfolio of beer brands, brewing beer in all available styles, especially ales such as stouts and IPAs. They usually try to refer to the global trends observed on the craft beer market, for example in the USA. In 2019, the number of unique beer premieres exceeded 2,400, whereas in 2013 it was 82 (see Fig. 3). A few years ago, only a dozen or so brands were well-known for Polish consumers. These days the most popular groups of styles are India Pale Ale (767 new unique beers in this style in 2019), Pale Ale (261), Stout (297), Sour Ale (268), and also Barrel Aged Beers (202 in 2018) - see Groń (2020).

The number of brewing entities in Poland, including contract breweries, increased rapidly between 2010 and 2019 from 70 to about 420 (Fig. 3). Such a rapid increase in the craft beer market was unknown in modern Polish history. In the analysed period, a systematic and continuous growth of new breweries was noted annually. What is relevant and worth emphasising, is that the number of medium-sized and large breweries has not changed: hence, small brewers are primarily responsible for the growth.

The craft beer revolution means not only a change in the number of new breweries and beers on the market, but also some external effects in socio-economic development and

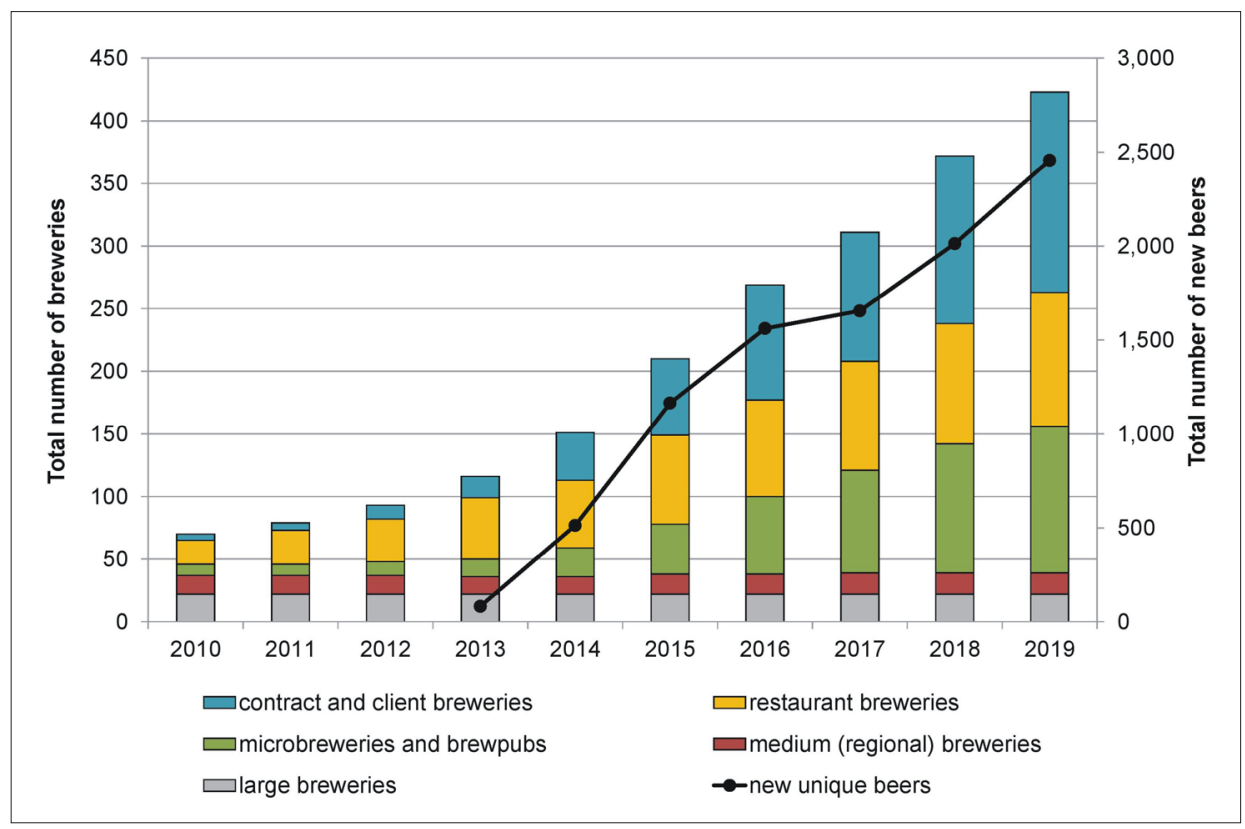

Fig. 3: Change in the number of breweries and new, unique beers delivered on the market annually in Poland during the Polish craft beer revolution Source: Based on The Beer Map and author's data collection

\footnotetext{
3 This term is variously defined depending on the country. It can be also defined as a beer firm, collaboration brewery, client brewery, gypsy brewers, phantom breweries, cuckoo breweries, etc. (see Swinnen and Garavaglia, 2018)

${ }^{4}$ See https://kilkaslowopiwie.com/2015/10/29/co-to-jest-piwo-rzemieslnicze-i-czym-jest-browar-rzemieslniczy/
} 
culture. People have started to 'groove' on beer history, the production process, etc. As a result, beer vlogs, blogs, and forums on the Internet have become very popular. Moreover, the number of new Polish nation-wide beer festivals has increased annually since 2010, from about 10 extant in 2013 to about 50 in 2018. Furthermore, the importance of beer tourism has been growing (Rogowski, 2016). The effects of the craft beer revolution has also helped Polish hop plantations, which suffered economically in the 2000s. What have also appeared on the market are historical and experimental Polish hops, e.g. Izabella, Oktawia, Tomyski, Iunga, Magnat, Puławski, Zula, or Polish Cascade (Portal Spożywczy, 2019) ${ }^{5}$.

\section{Results and discussion: Determinants of change in the craft beer market in Poland}

\subsection{The resource-partitioning model, niche market, and consumption habits}

Undoubtedly, from an economic point of view, the beer market in Poland after 1989 was heading towards oligopoly, so it was dominated by several large entities (Boratyńska, 2009). In 2017, Carlsberg Polska, Kompania Piwowarska/Asahi (formerly SAB Miller), and Żywiec Group/Heineken controlled 78.2\% of the Polish beer market (Deloitte, 2018). This can also be confirmed by analysing the market from the consumer side, because it should be recognised that the offered product is homogeneous, i.e. the consumer is not able to distinguish which industrial brewery the beer comes from (Allison and Uhl, 1964; Jacoby et al., 1971; Scherer, 1996; Moore et al., 2016). The product had been prepared to suit the widest target audience. Primarily, efficient marketing played a huge role in achieving this objective. Some observers have indicated the large impact of advertising on the increase in beer sales (e.g. George, 2009). In Poland, the dynamic development of television from the mid-1990s was particularly important. The advertisements drilled not only names of brands, but also consumer habits such as serving beer at a very low temperature, which was supposed to hide nuances in taste. As a result, beers from the largest brands were remembered in the minds of consumers as the International Pale Lagers that became the most often sold and bought style of beer in Poland.

Meanwhile, in response to the International Pale Lager flood on the market, consumers began to look for variety. In 2011, only craft breweries in Poland offered an alternative. This is why the first microbreweries on the market were so successful. Craft breweries produce a variety of atypical beers that satisfy sublime tastes. Besides, craft breweries are always associated with the work of a small, local, independent and innovative entity that provides customers with new and surprising taste experiences (Nilsson et al., 2019). Thus, consumers' needs lowered the market entry barrier, which encouraged others to open their own small breweries.

On the one hand, the established oligopoly still controlled the entire beer market for years, but on the other hand, it imposed specific requirements on its participants. Every large producer would have to take into account moves of the competition, which caused difficulties among oligopoly leaders in adapting to dynamic market changes (Hannan and Freeman, 1984). The spontaneous action is very risky. As a consequence, the largest brewing companies in Poland expanded their portfolio into beers from the ale family only a few years after the craft beer boom. The Kompania Piwowarska and Żywiec Brewery, launched in the period of the craft beer revolution, a series of beers referring directly to the craft beer wave - such as AIPA, APA, IRA, American Wheat, Saison, Witbier, Golden Ale, etc. These types of beers, however, still represented a small ratio of the sales volume of the industrial breweries.

What is worth emphasising is that the craft beer revolution in Poland, as compared with western markets, appeared later in time. On the one hand, it was because the country was functioning in the free market for only a relatively short time, and on the other hand, the international brewing companies

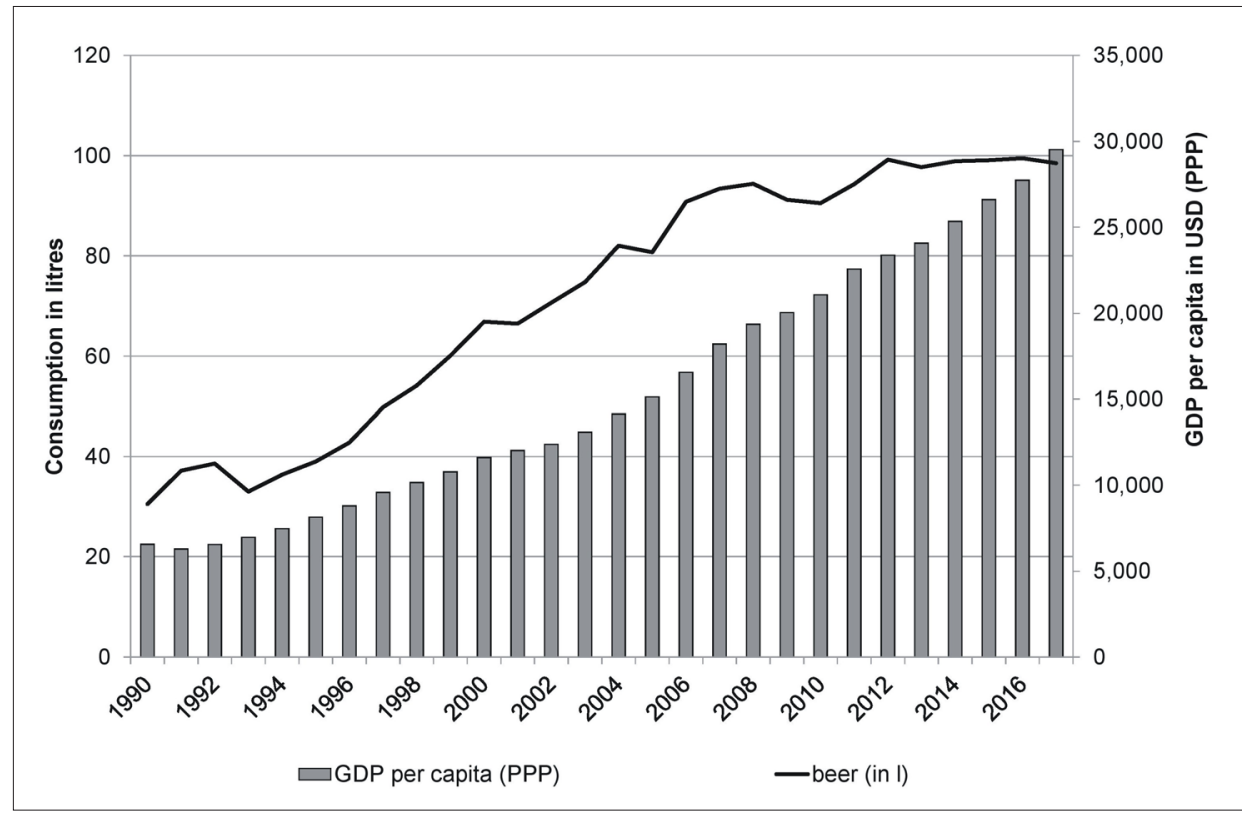

Fig. 4: Consumption of beer compared to GDP per capita in Poland between 1990 and 2017 Source: author's elaboration based on Statistics Poland and World Bank data

\footnotetext{
${ }^{5}$ See http://www.portalspozywczy.pl/alkohole-uzywki/wiadomosci/coraz-wiecej-polskich-odmian-chmielu,135496.html
} 
were aware that the beer industry was deeply rooted in Polish culture and Poles were loyal to what is local. This is due to the fact that beer is more closely intertwined with the concept of national identity and pride than other products, which is proved by the sales results of global brands (Stack et al., 2016). Therefore, the group's strategy called 'multitier', was to combine global and local brands (Chlebicka et al., 2018; Meyer and Tran, 2006). Sometimes, this strategy assumed the relocation of a beer brand production to another brewery. As K. Materna et al. (2020) noted, this process breaks the strong link between the brand and its place of origin. Originally, in Poland, this strategy of 'false regional identity' was successful, but the brewery products taken over by the concerns were 'unmasked' by consumers over time. In Poland, the operation of the resource-partitioning model also overlapped with other phenomena that supported this process. First of all, beer consumption in Poland has been rising regularly since 1990 (see Fig. 4).

With increasing consumption, the probability that part of the population will be open to new, unusual products increases, as is the case with innovation (Moore, 1999; Rogers, 1962). At the same time, average incomes in Polish society also increased at a similar rate, similar to the case of other middle- and low-income countries (Colen and Swinnen, 2015). The Pearson correlation coefficient for these two variables over the years $1990-2017$ was 0.93 . Studies show that high-income consumers are more likely to buy craft beer (Elzinga et al., 2015; Murray and O'Neill, 2012; Pokrivčák et al., 2019). B. Aquilani et al. (2015) report that particularly wealthy consumers in Italy have changed from premium lagers to special or craft beers. This is relevant because bottled craft beer in Poland is usually 3-4 times more expensive than the International Pale Lager from a large brewery. According to the Birofilia Report, beers that are not International Pale Lager attract consumers who can afford to pay 5-10 PLN and more (Birofilia, 2018).

In this respect, what is worth highlighting is that the income of residents of agglomeration areas in Poland, such as Warsaw, Wrocław, Gdańsk or Poznań, is higher than in other parts of the country (Statistics Poland, 2018), and primarily they have access to craft beer thanks to numerous craft beer pubs, specialist beer stores, or beer festivals (see Fig. 5). Thus, the craft beer revolution in Poland has the chance to develop quickly, especially in cities (Wojtyra et al., 2020).

Secondly, in comparison to the 1990s, along with growing income, consumer preferences in Poland have also changed significantly. In the analysed period, the consumption of strong alcohols decreased in favour of weaker alcoholic drinks, including beer (Krzemiński, 2013). In western Poland, patterns of alcohol consumption began to change gradually (Siemieniako et al., 2013): more and more people wanted to drink less, but drink better according to global key trends (Arthur, 2018).

An important factor in this situation is that although any deteriorating financial situation forces change in consumer preferences, it is difficult to give up acquired consumption habits and lifestyle (Śleszyńska-Świderska, 2013). Customers, who are satisfied with the change in beer consumption habits, will not be willing to accept the need to return to

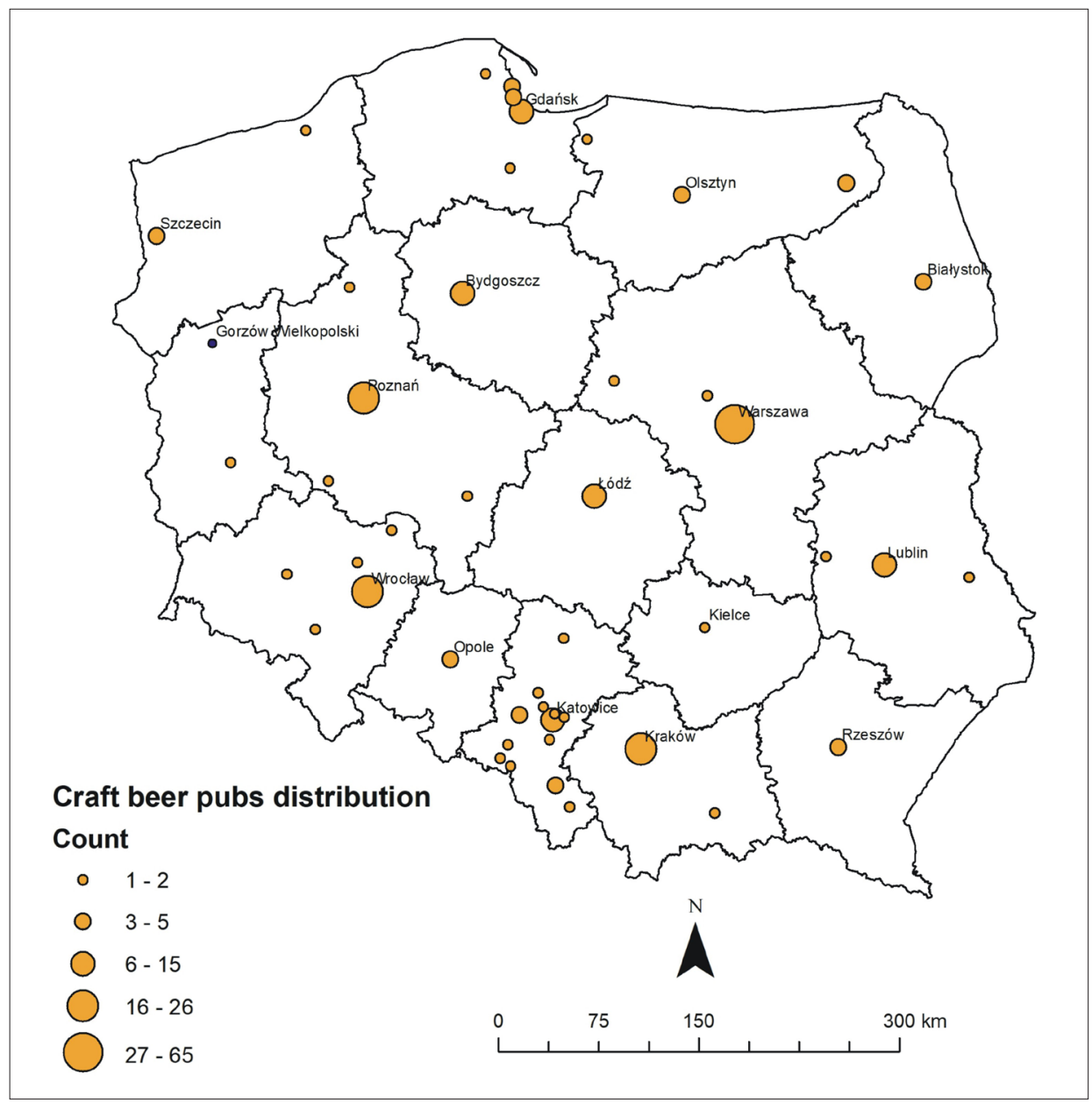

Fig. 5: Spatial distribution of craft beer pubs in Poland in 2019

Source: Based on The Beer Map and author's own data collection 
regular concern beers. In turn, a group of convinced craft beer drinkers eventually had a growing number of followers among consumers.

Thirdly, it is also significant that the Millennial generation plays an important role in the Polish craft beer revolution. According to the report for Birofilia (2018), in Poland young adults live and think quite differently than previous generations, they take the opportunity to choose, look for flavours, are not afraid of experiments. Young Millennials have no habits associated with the presence of alcohol volume in beverages, so experimenting with flavours, aromas, and brewing additives plays an increasingly important role. For $38 \%$ of the respondents up to 25 years old, a favorite beer style is pale lager. This is a significantly lower ratio than in a group of older people. Young adults, especially those living in agglomerations, are more eager to reach for beer specialties. In turn, older representatives of this generation are increasingly willing to pay a higher price for potentially higher quality.

\subsection{Globalisation, diffusion of innovation, and development of homebrewing}

The founders of the Pinta Brewery formed their ideas when travelling to the United States; and then they applied their knowledge about the craft beer market to Poland. That is why they could reproduce styles previously unknown to the average Polish consumer. In addition, they chose the right moment to spread the idea of craft beer because Polish society craved variety in the market. The Pinta Brewery had many followers and the number of new brewing entities began to increase rapidly in a short time. Products created in cooperation amply confirm this idea. In 2019 alone, Polish breweries cooperated in launching a new beer brand 80 times in foreign breweries and 65 times with other domestic craft breweries (Groń, 2018).

In Poland, home brewing has become an important foundation for the proliferation of craft brewing, as had taken place in other countries (Swinnen and Garavaglia, 2018). The predictability and boredom of the market offer caused an unexpected increase in the popularity of home brewing, which later evolved into contract, craft and restaurant brewing (Podeszwa, 2015). In fact, the tradition of home brewing in Poland dates back much earlier than the craft beer revolution. In 2001, one of the owners of the Pinta Brewery opened a store with products for home brewers. Then, in August 2010, an organisation bringing together the community of home brewers - the Polish Association of Home Brewers - was formally established, and it has now about 1,200 members. It is estimated that in Poland about 100,000 people brew beer at home. The increase in the number of home brewers is confirmed by the growing number of such registrations during home beer competitions (Birofilia, 2018).

Before microbreweries appeared in Poland, home brewers re-created and formulated recipes for beers not available on the domestic market. Therefore, the diversity of the beer world was known to them, and as soon as it became possible to use its resources on the domestic market, they used it as both consumers and producers. The community of home brewers became the foundation for the market. The increased activity of entrepreneurs in the beer industry created an opportunity for home brewers to commercialise their hobbies and to start a casual adventure with brewing on a commercial scale (Wojtyra et al., 2019). The creators of the Pinta Brewery took advantage of the experience they gained over the years as home brewers (Pinta, 2015). The low entry barrier and the exit one simplify the setting up of new contract breweries, for example (van Dijk et al., 2018).

As Polish industry experts note, there would be no beer revolution without home brewing, because professional brewers were not educated in Poland (Rogacyn, 2017). With the scarcity of Polish professional literature in the field of brewing, on-line groups and discussion panels, as well as foreign ones, which became a source of inspiration and knowledge, played an especially important role. Therefore, the experience of home brewers in the initial phase of the revolution was crucial for the newly-founded brewing entities.

\subsection{Neolocalism}

The case of the Polish craft beer market partially confirms this concept of the importance of the local. Many of the breweries strongly use brand-related marketing in their strategy and refer to locality. This situation applies essentially to stationary breweries, because of their permanent residence related to 'the place'. Neolocalism in this aspect manifests itself mainly in three ways. A studied local reference includes: the name of a brewery; the name of the beer; or a label that uses a symbol, a graphic, or a photograph referring to the locality. Among the 199 small and restaurant breweries in Poland that operated in 2018,86 (43\%) have a name that directly (place name, other geographical objects in the name) or indirectly (symbolism of the place, slogan related to local tradition, history, etc.) refers to the place in which the beer is brewed (see Tab. 1). In contrast, in the case of contract breweries, this phenomenon is rare. There is not such a strong connection with the place, because a contract brewery does not have a permanent brewing place ('gypsy brewing'). The name of only 29 out of the 89 classified contract breweries

\begin{tabular}{lccl}
\hline \multicolumn{1}{c}{ Name of brewery } & $\begin{array}{c}\text { Number of } \\
\text { microbreweries }\end{array}$ & $\begin{array}{c}\text { Number of } \\
\text { contract breweries }\end{array}$ & \multicolumn{1}{c}{ Examples } \\
\hline Name of city & 47 & 15 & $\begin{array}{l}\text { BroWarka, Karczewski, Miedzian- } \\
\text { ka, Milicz, Bednary, Łańcut }\end{array}$ \\
Name of other geographical object & 21 & 6 & $\begin{array}{l}\text { Dolina Bobru, Wieżyca, Pustynny } \\
\text { Other reference to locality }\end{array}$ \\
Total number of breweries in categories & 18 & 8 & $\begin{array}{l}\text { Bazyliszek, Stu Mostów, Hajer, } \\
\text { Za Miastem, Rock Browar Jarocin }\end{array}$ \\
Total number of breweries & 86 & 29 & - \\
Share [\%] & 199 & 89 & - \\
\hline
\end{tabular}

Tab. 1: Neolocalism references in the names of Polish craft breweries in 2019

Source: author's data collection 
can clearly relate to the region of origin. Such cases as the Szał Piw Poznań contract brewery, whose beer names are in dialectal language, are marginal.

Neolocalism may also explain how the craft beer market continues to grow. Craft breweries are often closer to their customers in the local community. Unlike large concerns, the brew-master of a small brewery is often well-known by name (as mentioned in "Kraft Roku"). What is more, the brewery representatives are involved in supporting local events, such as beer festivals, tap takeover in craft beer pubs, and seasonal events, creating a community that advertises the region. Emphasising local identity and uniqueness, microbreweries use targetted marketing strategies and intentionally satisfy the desire to connect with the local community.

In Poland, this factor is relevant, but is not a key determinant, if one compares these results with the map of craft beer pubs where the biggest cities dominate. According to the "Portrait of a Polish craft beer drinker", about 70\% of beer customers live in a city with a population larger than 150,000. Craft beer, although consumed and produced mainly in cities and their agglomerations, is also produced in smaller centers. Craft beers coming from different regions are available in the whole country, however, so the sale is not only local (Gron, 2015). While the marketing strategy is not based on neolocalism, it is targetted at a specific group of regular customers known as 'beergeeks' (birophiles), who are keenly interested in craft beer. Analysing the form of advertising, it can be observed that the craft breweries in Poland professionally manage profiles in social media and gather this target audience. Groups on Facebook like "Jepiwka" (14,000 members in 2019) devoted to discussions about the Polish craft beer market, the recommendation system available on Internet websites and apps like Untappd, where anyone can evaluate and describe tasted beers, have evolved rapidly during the beer revolution.

The need for variety, especially among beergeeks, has caused a lot of consumers to still look for new beers. They just want to sample another beer. They reluctantly come back to beers which they drank and rarely show brand loyalty. As a result, the phenomenon of hyper-differentiation can be observed. In 2019, the number of unique beer premieres exceeded 2,400. Every year, the most fertile breweries present between 30 and 50 new beers. Only in 2019, three Polish breweries brewed and launched more than 50 new, unique beers: Ziemia Obiecana (63), Funky Fluid (51), and Piwne Podziemie (51).

\subsection{Path dependence}

The decisions regarding the larger concerns' strategy and the appearance of the Pinta Brewery determined the further development of the beer market in Poland. Moreover, the historical and geographical context, presented in more detail in the first part of this article, also influenced those events. As Niemczyk (2017) observed, the International Pale Lager as a style of beer dominating the Polish beer market from the supply side is the culmination of brewing art subjected to the strict rigors of large-scale production and distribution. Therefore, it is natural that every producer who wants to gain a large market share must offer high quality lagers at a good price (cf. Niemczyk, 2017).

Polish large breweries are locked into brewing industry standards. The turning point in the development of the beer market in Poland, as already mentioned, is the introduction of the first AIPA brewed by a Polish brewery. This event determined everything that took place after its occurrence.
It is hard to imagine that in the near future there would be a complete return to the situation before the craft beer revolution. The decisions taken by brewing companies, which at the turn of the $21^{\text {st }}$ century focused completely on the production of one style of beer, mean that today they have difficulties in adapting to economic and cultural changes. Medium-sized and small breweries in recent years have taken advantage of the internal drawback of the beer oligopoly and shaped a new path (Niemczyk, 2017). Tomasz Kopyra, a Polish expert in the field of brewing and the author of one of the most popular vlogs about beer in the world, noted that (translated from Polish language by the author):

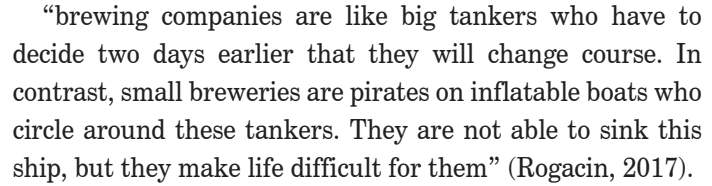

"brewing companies are like big tankers who have to decide two days earlier that they will change course. In contrast, small breweries are pirates on inflatable boats who circle around these tankers. They are not able to sink this ship, but they make life difficult for them" (Rogacin, 2017).

Of course, the innovation dynamics have also been replicated by the three main brewing companies, which started to diversify portfolios and gradually introduced new styles. Their offer, however, is still sparse in comparison to craft breweries. Moreover, their reaction was late and generated by the emergence of the microbreweries.

\section{Conclusions}

This article has investigated the principal reasons behind the proliferation of craft breweries in Poland. The craft beer revolution is a kind of socio-economic phenomenon, which occurred contrary to the principles of classical economics and the rules of the development of an oligopolistic market. The phenomenon has shown that diversity and the ability to choose from a wide range of products can be important for the customer, and beer can be a commodity of high quality with its price and marketing strategy different to those imposed by oligopoly members.

As J. Swinnen and C. Garavaglia (2018, p. 3) write:

"Craft brewers and their customers have transformed global beer markets over the past two decades. They ended a century of consolidation of breweries, resulting in the domination of a few global multinationals and the homogenisation of beer. They started small and isolated, but ultimately transformed a global industry. Their counterrevolution against the domination of the macrobrewers and their uniform beer styles has totally transformed the global beer scene."

The reasons for the emergence and development of the craft beer industry in Poland are summarised in the following model (Fig. 6). The turning points were the years 1989 and 2011. The first concerns the moment when socialism collapsed in Poland, which resulted in the opening of the market and the emergence of international brewing concerns. The second date is the commonly-accepted beginning of the craft beer revolution, when the Pinta Brewery was the first to introduce a previously unknown beer in the style of AIPA to the market, a time referring to the trends present in other countries, including primarily the USA.

Many factors influenced the creation and development of this phenomenon. Some were analogous to those that appeared earlier in other beer markets in the world and can be based on theories and concepts related to economics or socio-economic geography, for example the resourcepartitioning model, a niche market, neolocalism, path dependence, or the diffusion of innovations. Other reasons result from the specifics of the Polish market and changes 


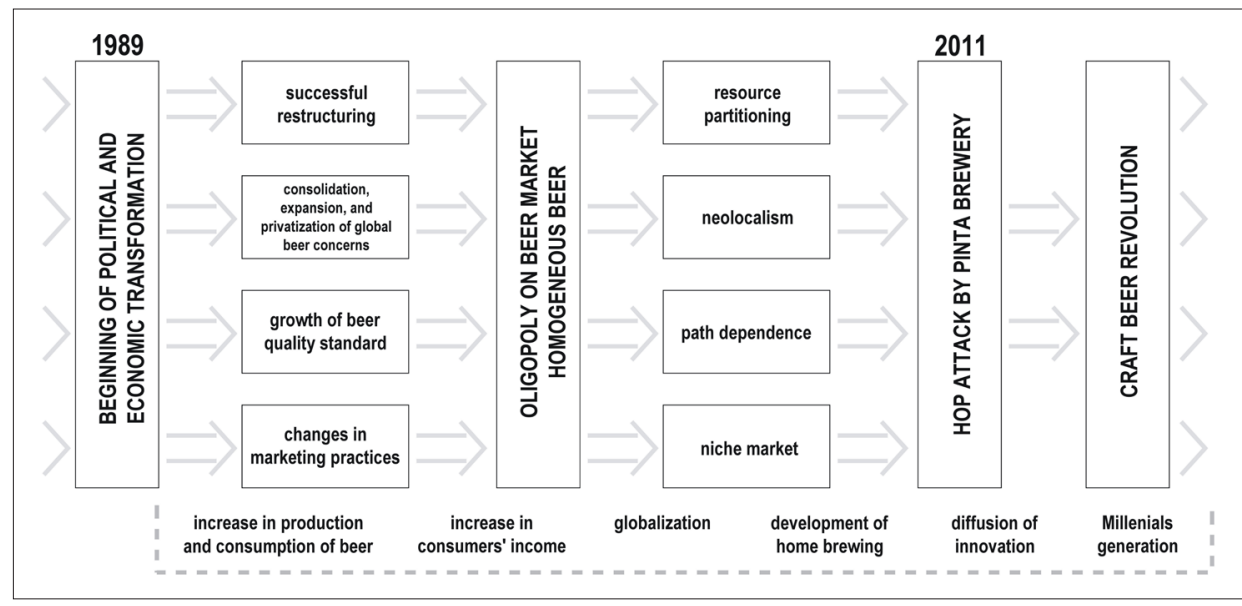

Fig. 6: Cause and effect diagram - determinants of changes in the beer market in Poland Source: author's elaboration

in its environment, among them the domestic increase in beer production and consumption, the dynamic growth of inhabitants' incomes, and the great success of large brewing companies in the 1990 s and 2000 s, which occasioned the later start of the beer revolution. No doubt, some of the individual elements need to be examined in more detailed tests.

The increase in the number of breweries in the period 2011-2019 maintains an exponential trend. The same is true for the number of new craft beers that are introduced in the market. Interest in the craft beer market is growing. As far as supply is concerned, the observed phenomenon is strongly embedded. It seems to have an irreversible course and consumers are already accustomed to the presence of craft beer in stores. Taking into account the markets where the beer revolution has lasted longer, as well as the scale of the Polish market and production volume as well as consumption, one can expect a further increase in the importance of this sector. According to the Polish Association of Home Brewers (2019), the share of craft beers in the Polish brewing market is around $1.6-2.0 \%$ of sales volume.

Although this phenomenon is referred to as a "revolution", it is rather evolutionary in its nature when considering the demand. The control of the beer market taken over by the three international brewing companies resulted in Polish society getting 'stuck' in their attachment to International Pale Lager. Therefore, the change in preferences for the vast majority of consumers is a very difficult and long-lasting process. It is difficult to judge whether it is achievable at all.

\section{References:}

ACITELLI, T. (2013): The Audacity of hops: The history of America's craft beer revolution. Chicago, Chicago Review Press.

ALLISON, R. I., UHL, K. P. (1964): Influence of beer brand identification on taste perception. Journal of Marketing Research, 1(3): 36-39.

AQUILANI, B., LAURETI, T., POPONI, S., SECONDI, L. (2015): Beer choice and consumption determinants when craft beers are tasted: An exploratory study of consumer preferences. Food Quality and Preference, 41: 214-224.

ARNOLD, J.P. (2005): Origin and History of Beer and Brewing: From Prehistoric Times to the Beginning of Brewing Science and Technology, Cleveland, OH: Beer Books, reprint edition.
ARTHUR, B. (1989): Competing technologies, increasing returns, and lock-in by historical events. Economic Journal, 99: 116-131.

ARTHUR, R. (2018): The key trend in the global beer industry? 'Drinking less, but drinking better'. Beverage Daily, 05-06-2018 [online]. Available at: https://www. beveragedaily.com/Article/2018/06/05/Drinking-less-butdrinking-better-Key-trends-in-the-global-beer-industry

BAGINSKI, J., BELL, T. L. (2011): Under-Tapped?: An Analysis of Craft Brewing in the Southern United States. Southeastern Geographer, 51(1): 165-185.

BELL, T. R. (2017): What's in a name? Cultural Heritage and naming praxis in Tampa Bay Craft Breweries. In: Tyma, A. W. [ed.]: Beer Culture in theory and practice. Understanding Craft Beer Culture in the United States (pp. 97-111). Lanham, MD, Lexington Books.

BEER JUDGE CERTIFICATION PROGRAM (2015): Beer Style Guidelines [online]. [cit. 17.08.2019]. Available at: https://www.bjcp.org/ docs/2015_Guidelines_Beer.pdf

BIROFILIA (2018): Milenialsi a piwo. Raport z badania społeczności [online]. [cit. 17.05.2020]. Available at: https://birofilia.org/uploads/oryginal/5/0/9ab7e22e birofilia_raport_millenialsi_a.pdf

BLAIECH, R., GHARBI, A., HAMOUDA, M. (2013): Postmodern Marketing: Towards a Convergence between the Individualistic Approach and the Tribal Approach. Interdisciplinary Journal of Contemporary Research in Business, 4(9): 1294-1307.

BLECHER, E., LIBER, A., VAN WALBEEK, C., ROSSOUW, L. (2018): An international analysis of the price and affordability of beer. PLoS ONE, 13(12): e0208831.

BORATYŃSKA, L. (2009): Rynek piwa w Polsce i perspektywy jego rozwoju. Zeszyty Naukowe SGGW w Warszawie. Ekonomika i Organizacja Gospodarki Żywnościowej, 75: 5-13.

BOROWSKA, A. (2009): Przemiany na rynku napojów alkoholowych w Polsce w latach 1990-2007. Zeszyty Naukowe Szkoły Głównej Gospodarstwa Wiejskiego w Warszawie. Problemy Rolnictwa Światowego, 9(24): 15-26.

BOURDIEU, P. (1984): Distinction: A Social Critique of the Judgement of Taste. Cambridge, (MA): Harvard University Press. 
BRZEZIŃSKI, M. (2001): Zarządzanie innowacjami technicznymi i organizacyjnymi. Warszawa, Difin.

CABRAS, I., BAMFORTH, C. (2015): From reviving tradition to fostering innovation and changing marketing: The evolution of micro-brewing in the UK and US, 1980 2012. Business History, 58(5): 625-646.

CABRAS, I., HIGGINS, D., PREECE, D. (2016): Brewing, Beer and Pubs: A Global Perspective. London, Palgrave Macmillan.

CABRAS, I., HIGGINS, D. (2016): Beer, brewing, and business history. Business History, 58(5): 609-624.

CARROLL, G. R. (1985): Concentration and specialization: Dynamics of niche width in populations of organizations. American Journal of Sociology, 90(6): 1261-1283.

CARROLL, G. R.,HANNAN,M. T.(1995): ResourcePartitioning. In: Carroll, G. R., Hannan, M. T. [eds.]: Organizations in Industry: Strategy, Structure and Selection (pp. 215-221). New York, Oxford University Press.

CARROLL, G., SWAMINATHAN, A. (2000): Why the microbrewery movement? Organizational dynamics of resource partitioning in the US brewing industry. The American Journal of Sociology, 106(3): 715-762.

CARROLL, G., DOBREV, S. D., SWAMINATHAN, A. (2002): Organizational process of resource partitioning. Research in Organizational Behaviour, 24: 1-40.

CAVES, R., PORTER, M. E. (1977): From entry barriers to mobility barriers: conjectural decisions and contrived deterrence to new competition. Quarterly Journal of Economics, 91(2): 241-261.

CHLEBICKA, A., FAŁKOWSKI, J., LICHOTA, J. (2018): From Macro to Micro: The change of trendsetters on the Polish beer market. In: Swinnen, J., Garavaglia, C. [eds.]: Economic Perspectives on Craft Beer. A revolution in the global beer industry (pp. 295-319). Cham, Palgrave Macmillan.

CHOI, D. Y., STACK, M. H. (2005): The all-American beer: a case of inferior standard (taste) prevailing? Business Horizons, 48(1): 79-86.

CLEMONS, E. K., SPITLER, R., GU, B., MARKOPOULOS, P. (2003): Information, hyper-differentiation, and delight: the value of being different, information: strategy, systems, and economics. Strategy, Systems, and Economics The Wharton School, The Wharton School.

CLEMONS, E. K., GAO, G., HITT, L. M. (2006): When online reviews meet hyperdifferentiation: a study of the craft beer industry. Journal of Management Information System 23(2): 149-171.

COLEN, L., SWINNEN, J. (2015): Economic Growth, Globalisation and Beer Consumption. Journal of Agricultural Economics, 67(1): 186-207.

DAVID, P. (1985): Clio and the economics of QWERTY. American Economic Review, Papers and Proceedings, 75: 332-337.

DELOITTE (2018): Podsumowanie analizy wybranych wskaźników wpływu przemysłu piwowarskiego na polską gospodarkę i otoczenie [online]. ZPPP Browary Polskie report [cit. 05.09.2019]. Available at: https://browarypolskie.pl/wp-content/uploads/2018/11/Raport-Deloitte.pdf

DSM (2018): The Craft Revolution in brewing - report [online]. [cit. 17.08.2019]. Available at: https:// gastronomiaycia.republica.com/wpcontent/ uploads/ 2018/06/cerveza_artesana_estudio.pdf

DUARTE ALONSO, A., ALEXANDER, N., O'BRIEN, S. (2018): Collaboration and the Emerging Craft Brewing Industry: An Exploratory Study. Journal of Asia-Pacific Business, 19(3): 203-224.

DYBKA, S. (2015): Kierunki zmian preferencji konsumentów w odniesieniu do produktów i detalistów. Handel Wewnętrzny, 4(357): 200-210.

EBERTS, D. (2014): Neolocalism and the branding and marketing of place by Canadian microbreweries. In: Patterson, M., Hoalst-Pullen, N. [eds.]: The geography of beer: Regions, environment, and societies (pp. 189-199). New York/London, Springer Dordrecht Heidelberg.

ELZINGA, K. G., TREMBLAY, C. H., TREMBLAY, V. J. (2015): Craft Beer in the United States: History, Numbers, and Geography. Journal of Wine Economics, 10(3): 242-274.

ESPOSTI, R., FASTIGI, M., VIGANÒ, E. (2017): Italian craft beer revolution: do spatial factors matter? Journal of Small Business and Enterprise Development, 24(3): 503-527.

FASTIGI, M., VIGANÒ, E., ESPOSTI, R. (2018): The Italian microbrewing experience: features and perspectives. Biobased and Applied Economics, 7(1): 59-86.

FLACK, W. (1997): American microbreweries and neolocalism: "Ale-ing" for a sense of place. Journal of Cultural Geography, 16(2): 37-53.

FLYVBJERG, B. (2006): Five misunderstandings about case study research. Qualitative Inquiry, 12(2): 219-245.

FREEMAN, J., HANNAN, M. T. (1983): Niche width and the dynamics of organizational populations. American Journal of Sociology, 88: 1116-1145.

GARAVAGLIA, C. (2020): The Emergence of Italian Craft Breweries and the Development of Their Local Identity. In: Hoalst-Pullen, N., Patterson, M. [eds.]: Geography of Beer: Culture and Economics (pp. 135-148). Cham, Springer.

GATRELL, J., REID, N., STEIGER, T. L. (2018): Branding spaces: Place, region, sustainability and the American craft beer industry. Applied Geography, 90: 360-370.

GEORGE, L. M. (2009): National television and the market for local products: The case of beer. Journal of Industrial Economics, 57(1): 85-111.

GERRING, J. (2006): Case Study Research: Principles and Practices. New York, Cambridge University Press.

GIDDENS, A. (1990): The Consequences of Modernity. Stanford, CT, Stanford University Press.

GOŁAŚ, Z., ŚCIBEK, M. (2010): Analiza tendencji zmian na polskim rynku piwa. Journal of Agribusiness and Rural Development, 1(15): 67-80.

GROŃ, K. (2015): Portret polskiego kraftopijcy [online]. [cit. 17.05.2020]. Available at: http://www.zwrotnica.com. pl/2015/04/17-marca-rozpoczelismy-nasza-ankiete.html

GROŃ, K. (2018): Piwne podsumowanie 2018 [online]. [cit. 22.04.2020]. Available at: http://www.zwrotnica.com. pl/2018/12/piwne-podsumowanie-2018.html

GROŃ, K. (2020): Piwne podsumowanie 2019 [online]. [cit. 22.04.2020]. Available at: http://www.zwrotnica.com. pl/2020/01/piwne-podsumowanie-2019.html 
HÁNA, D., MATERNA, K., HASMAN, J. (2020). Winners and losers of the global beer market: European competition in the view of product life-cycle. Cambridge Journal of Economics, beaa006.

HANNAN, M. T., FREEMAN, J. (1984): Structural inertia and organizational change. American Sociological Review, 49(2): 149-164.

HARVEY, D. (1989): The Condition of Postmodernity. Oxford, Blackwell.

HINDY, S. (2014): The Craft Beer Revolution: How a Band of Microbrewers Is Transforming the World's Favorite Drink. New York, Palgrave Macmillan.

HOLTKAMP, C., SHELTON, T., DALY, G., HINER, C. C., HAGELMAN III, R. R. (2016): Assessing Neolocalism in Microbreweries. Papers in Applied Geography, 2(1):66-78.

HORNSEY, I. S. (2003): A history of beer and brewing. United Kingdom, the Royal Society of Chemistry.

HOWARD, P. H. (2014): Too Big to Ale? The Globalization and Consolidation in the Beer Industry. In: Patterson, M., Hoalst-Pullen, N. [eds.]: The geography of beer: Regions, environment, and societies (pp. 155-165). New York/ London, Springer Dordrecht Heidelberg.

HUCULAK, M. (2004): Przekształcenia własnościowe w przemyśle piwowarskim Polski po 1990 roku. Prace Komisji Geografii Przemysłu Polskiego Towarzystwa Geograficznego, 7: 71-86.

HUCULAK, M. (2010): Funkcjonowanie przemysłu piwowarskiego w przestrzeni gospodarczej Polski w okresie transformacji, Instytut Geografii i Gospodarki Przestrzennej UJ, PhD thessis (working version).

JACOBY, J., OLSON, J. C., HADDOCK, R. A. (1971): Price, brand name, and product composition characteristics as determinants of perceived quality. Journal of Applied Psychology, 55(6): 570-579.

KHERMOUCH, G. (1995): A different brew. Brandweek, 36(44): $25-29$

KLIMEK, K. (2014): Ewolucja rynku piwa w Polsce. Stowarzyszenie Ekonomistów rolnictwa i agrobiznesu. Roczniki naukowe, 2(16): 117-122.

KOPEĆ, M., MITERA, K. (2014): Rozwój piwowarstwa w Polsce w okresie poakcesyjnym. Progress in Economic Sciences, 1: 75-83.

KRZEMIŃSKI, M. [ed.] (2013): Produkcja alkoholi, Rynek używek. Cz. I Rynek alkoholu i napojów alkoholowych, stan i perspektywy. Analizy Rynkowe. Instytut Ekonomiki Rolnictwa i Gospodarki Żywnościowej Państwowy Instytut Badawczy, Warszawa.

KUHN, T. S. (1987): What are scientific revolutions? In: Kruger, L., Daston, L. J., Heidelberger, M. [eds.]: The probabilistic revolution, Vol. 1: Ideas in history (pp. 7-22). Cambridge, MA: MIT Press.

ŁOBOS, K., SZEWCZYK, M. (2013): Dystrybucja efektów koncentracji sektora piwowarskiego wśród dużych i małych przedsiębiorstw operujących na rynku polskim w latach 2004-2011. Journal of Agribusiness and Rural Development, 4(30): 149-159.

ŁUŻAK, T. (2017): Strategie niszy rynkowej na przykładzie sektora browarów w Polsce. Studia i Prace Kolegium Zarządzania i Finansów, 53: 193-209.
MARTIN, R. (2010): Rethinking regional path dependence: beyond lock-in to evolution. Economic Geography, 86(1): 1-27.

MASTANJEVIĆ, K., KRSTANOVIĆ, V., LUKINAC, J., JUKIĆ, M., LUČAN, M., MASTANJEVIĆ, K. (2019): Craft brewing - is it really about the sensory revolution? Kvasny prumysl, 65: 13-16.

MASZKOWSKI, W., WYSOKIŃSKI, M. (2017): Dystrybucja piwa w mikro i małych browarach w Polsce. Roczniki Naukowe Stowarzyszenia Ekonomistów Rolnictwa i Agrobiznesu, 19(6): 159-164.

MATERNA, K., HASMAN, J., HÁNA, D. (2019) Acquisition of industrial enterprises and its relations with regional identity: The case of the beer industry in Central Europe, Norsk Geografisk Tidsskrift - Norwegian Journal of Geography, 73(4): 197-214.

MATHIAS, B. D., HUYGHE, A., FRID, C. J, GALLOWAY, T. L. (2018): An identity perspective on coopetition in the craft beer industry. Strategic Management Journal, 39: 3086-3115.

MEYER, K., TRAN, Y. (2006): Market Penetration and Acquisition Strategies for Emerging Economies. Long Range Planning, 39(2): 177-197.

MOON, W., FLORKOWSKI, W., BRUCKNER, B., SCHONHOF, I. (2002): Willingness to pay for environmental practices: Implications for eco-labeling. Land Economics, 78(1): 88-102.

MOORE, G. A. (1999): Crossing the Chasm, Marketing and Selling High-Tech Products to Mainstream Customer (revised edition), New York, HarperCollins Publishers.

MOORE, M. S., REID, N., MCLAUGHLIN, R. B. (2016): The Locational Determinants of Micro-breweries and Brewpubs in the United States. In: Cabras, I., Higgins, D., Preece, D. [eds.]: Brewing, Beer and Pubs: A Global Perspective (pp. 182-204). Palgrave Macmillan, London.

MURRAY, D. W., O'NEILL, M. A. (2012): Craft beer: penetrating a niche market. British Food Journal, 114(7): 899-909.

NIELSEN (2015): Tapped in: Craft and local are powerful trends in the beer aisle [online]. [cit. 29.08.2019]. Available at: http://www.nielsen.com/us/en/insights/ news/2015/tapped-in-craft-and-local-are-powerfultrendsin-the-beer-aisle.html

NIEMCZYK, L. (2017): Mikrobrowary jako element rozwoju regionalnego w Polsce i na Podkarpaciu. Przedsiębiorstwo i Region, 9: 49-57.

NILSSON, I., REID, N., LEHNERT, M. (2018): Geographic patterns of craft breweries at the intraurban scale. The Professional Geographer, 70(1): 114-125.

O'BRIEN, J. (2020): The Branding Geography of Surrey Craft Breweries. In: Hoalst-Pullen, N., Patterson, M. [eds.]: Geography of Beer: Culture and Economics (pp. 23-34). Cham, Springer.

OLIVER, G. (2011): Craft Brewing. The Oxford Companion to Beer. New York, Oxford University Press.

PATTERSON, M., HOALST-PULLEN, N. (2014): Geography of Beer. Regions, Environment, and Societies. New York/ London, Springer Dordrecht Heidelberg. 
PINTA (2015): About Us [online]. [cit. 17.05.2020]. Available at: http://www.browarpinta.pl/en/about-us.html

PIRON, E., POELMANS, E. (2016): Beer, the Preferred Alcoholic Drink of All? Changes in the Global and National Beer Consumption since 1960 and Convergence and Trends since the 1990s. In: Cabras, I., Higgins, D., Preece, D. [eds.]: Brewing, Beer and Pubs (pp. 205-227). London, Palgrave Macmillan.

PODESZWA, T. (2015): Browarnictwo rzemieślnicze (craft-brewing) - oddolna aktywność mikrowytwórców stymulantem rozwoju rynku i samokształcenia w zakresie browarnictwa. Acta Innovations, 15: 56-61.

POKRIVČÁK, J., CHOVANOVÁ SUPEKOVÁ, S., LANČARIČ, D., SAVOV, R., TÓTH, M., VAŠINA, R. (2019): Development of beer industry and craft beer expansion. Journal of Food and Nutrition Research, 58(1): 63-74.

POLISH ASSOCIATION OF HOME BREWERS (2019). Report [online]. [cit. 22.04.2020]. Available at: https:// pspd.org.pl/wp-content/uploads/2017/03/Browaryrzemie\%C5\%9Blnicze-stanowi\%C4\%85-ok.-2-proc.rynku.-Ich-udzia\%C5\%82-w-ci\%C4\%85gu-kilku-latmo\%C5\%BCe-wzrosn\%C4\%85\%C4\%87-do-10-proc.-1.pdf

PORTER, M. E. (1980): Competitive strategy: Techniques for analyzing industries and competitors. New York, Free Press.

PRAHALAD, C. K., RAMASWAMY, V. (2004): Co-creating unique value with customers. Strategy and Leadership, 32(3): 4-9.

RAO, H. (2008) Market rebels: How activists make or break radical innovations. New York, Princeton, Princeton University Press.

REID, N., MCLAUGHLIN, R. B., MOORE, M. S. (2014): From Yellow Fizz to Big Biz: American Craft Beer Comes of Age. Focus on Geography, 57(3): 114-125.

RICE, J. (2016): Professional Purity: Revolutionary Writing in the Craft Beer Industry. Journal of Business and Technical Communication, 30(2): 236-261.

RITZER, R. (1993): The McDonaldization of Society: An Investigation into the Changing Character of Contemporary Social Life. Newby Park, Thousand Oaks (CA), Pine Forge Press.

ROBERTSON, R. (1994): Globalisation or glocalisation? The Journal of International Communication, 1: 33-52.

ROGACIN, K. (2017): Tomasz Kopyra: Piwna rewolucja w Polsce dopiero się zacznie. Polska Times, 29-122017 [online]. [cit. 17.05.2020]. Available at: https:// polskatimes.pl/tomasz-kopyra-piwna-rewolucja-wpolsce-dopiero-sie-zacznie/ar/c3-12805076

ROGERS, E. (1962): Diffusion of innovations ( $1^{\text {st }}$ ed.). New York, Free Press of Glencoe.

ROGOWSKI, M. (2016): Turystyka piwna w Polsce-aktualne uwarunkowania rozwoju oraz sylwetka i zainteresowania biroturysty. Zeszyty Naukowe. Turystyka i Rekreacja, 1(17): 207-226.

SCHERER, F. M. (1996): Industry Structure, Strategy, and Public Policy. New York, HarperCollins.

SCHNELL, S. M., REESE, J. F. (2003): Microbreweries as tools of local identity. Journal of Cultural Geography, 21(1): 45-69.
SCHNELL, S. M. (2013): Deliberate identities: Becoming local in America in a global age. Journal of Cultural Geography, 30(1): 55-89.

SCHNELL, S. M., REESE, J. F. (2014): Microbreweries, Place, and Identity in the United States. In: Patterson, M., Hoalst-Pullen, N. [eds.]: The Geography of Beer. Regions, Environment, and Societies (pp. 167-188). New York/ London, Springer Dordrecht Heidelberg.

SIEMIENIAKO, D., KUBACKI, K., GLIŃSKA, E., KROT, K. (2011): National and regional ethnocentrism: a case study of beer consumers in Poland. British Food Journal, 113(3): 404-418.

ŚLESZYŃSKA-ŚWIDERSKA， A. (2013): Skłonności konsumpcyjne Polaków w warunkach kryzysu gospodarczego. Zeszyty Naukowe SGGW w Warszawie. Polityki Europejskie. Finanse i Marketing, 9(58): 559-576.

STACK, M., GARTLAND, M., KEANE, T. (2016): Path Dependency, Behavioral Lock-in and the International Market for Beer. In: Cabras, I., Higgins, D., Preece, D. [eds.]: Brewing, Beer and Pubs (pp. 54-73). London, Palgrave Macmillan.

STAKE, R.E. (1995): The art of case study research. Thousand Oaks, CA, Sage.

STATISTICS POLAND (2018): Statistics Poland [online). [cit. 08.11.2019]. Available at: www.stat.gov.pl

SWAMINATHAN, A. (1998): Entry into new market segments in mature industries: Endogenous and exogenous segmentation in the US brewing industry. Strategic Management Journal, 19: 389-404.

SWINNEN, J., VAN HERCK, K. (2011): How the East was Won: The Foreign Takeover of the Eastern European Brewing Industry. In: Swinnen, J. [ed.]: The Economics of Beer (pp. 247-264). Oxford, Oxford University Press.

SWINNEN, J., GARAVAGLIA, C. [eds.] (2018): Economic Perspectives on Craft Beer. A revolution in the global beer industry (pp. 3-54). Cham, Palgrave Macmillan.

SZAJNER, P. (2017): Ewolucja rynku piwa w Polsce [online]. Instytut Ekonomiki Rolnictwa i Gospodarki Żywnościowej. Państwowy Instytut Badawczy. [cit. 10.09.2019]. Available at: https://www.ierigz.waw.pl/ aktualnosci/seminaria-i-konferencje/21721,17,3,0,semin arium-ewolucja-rynku-piwa-w-polsce.html

SZYMAŃSKI, M. J. (2018): Polskie piwo. Biografia (historia lekko podchmielona). Warszawa, Fronda.

THE BREWERS OF EUROPE (2018) Beer statistics 2018 edition [online]. [cit. 29.08.2019]. Available at: https:// brewersofeurope.org/uploads/mycms-files/documents/ publications/2018/EU-beer-statistics-2018-web.pdf

TOMSKI, P., MENDERAK, R. (2019): Contract Brewing Production-Oriented Cooperation in Craft Brewing Industry. Production Engineering Archives, 22: 16-23.

TORO-GONZÁLEZ,T., MCCLUSKEY,J. J., MITTELHAMMER, R. C. (2014): Beer Snobs Do Exist: Estimation of Beer Demand by Type. Journal of Agricultural and Resource Economics, 39(2): 1-14.

VAN DIJK, M., KROEZEN, J., SLOB, B. (2018): From Pilsner desert to craft beer oasis: The rise of craft brewing in the Netherlands. In: Swinnen, J., Garavaglia, C. [eds.]: Economic Perspectives on Craft Beer. A revolution in the global beer industry (pp. 259-293). Cham, Palgrave Macmillan. 
WOJTYRA, B., GRUDZIEŃ, Ł., LICHOTA, J. (2019): The role of contract brewers in Poland's beer revolution [online]. Beeronomics 2019 [cit. 20.10.2019]. Available at: https:/ www.slideshare.net/janlichota/the-role-of-contractbrewers-in-the-polish-beer-revolution-beeronomics-2019

WOJTYRA, B., GRUDZIEŃ, Ł. (2017): The Development of the Beer Industry in Poland During "The Craft Beer Revolution" (2011-2016). Studies of the Industrial Geography Commission of the Polish Geographical Society, 31(1): 52-67.

WOJTYRA, B., GRUDZIEŃ, Ł., LICHOTA, J. (2020): The (r)evolution of the craft beer scene in Poland after 2010 In: Hoalst-Pullen, N., Patterson, M. [eds.]: Geography of Beer: Culture and Economics (pp. 47-65). Cham, Springer.
YEAGER, C., GATRELL, J. D. (2020): Brewpubs and Microbreweries: A Midwestern Geography of Local Craft Beer Markets by Firm Type. In: Hoalst-Pullen, N., Patterson, M. [eds.]: Geography of Beer: Culture and Economics (pp. 159-168). Cham, Springer.

YIN, R. K. (2009): Case study research design and methods ( $4^{\text {th }}$ ed.). Applied Social Research Method Series Vol. 5. Thousand Oaks, CA, Sage.

ZUCHELLA, A., PALAMARA, G. (2007): Niche strategy and export performance. Advances in International Marketing, 17(1): 63-87.

\section{Please cite this article as:}

WOJTYRA, B. (2020): How and why did craft breweries 'revolutionise' the beer market? The case of Poland. Moravian Geographical Reports, 28(2): 81-97. Doi: https://doi.org/10.2478/mgr-2020-0007 